\title{
Genotypic and Phenotypic Path Analysis for Flower Yield in Chrysanthemum (Dendranthema grandiflora Tzvelve)
}

\author{
Mallikarjun Hebbal $^{1 *}$, Mukund Shiragur ${ }^{1}$, Sandhyarani Nishani ${ }^{2}$, B.C. Patil ${ }^{1}$, \\ G.K. Seetharamu ${ }^{1}$ and Mahantesha B.N. Naika ${ }^{2}$ \\ ${ }^{I}$ Department of Floriculture and Landscape Architecture, University of Horticultural \\ Sciences, Bagalkot, Karnataka, India \\ ${ }^{2}$ Department of Crop Improvement and Biotechnology, KRCCH, Arabhavi-591218, University \\ of Horticultural Sciences, Bagalkot, Karnataka, India \\ *Corresponding author
}

A B S T R A C T

\begin{tabular}{|l|}
\hline Ke y w or d s \\
Path coefficient analysis, \\
Flower yield, \\
Dendranthema \\
grandiflora Tzvelve
\end{tabular}

Ten genotypes of chrysanthemum (Dendranthema grandiflora Tzvelve) were assessed for 12 quantitative and qualitative traits to study the path analysis of different parameters with yield components and their direct and indirect effects on flower yield. Genotypic path coefficient analysis revealed that flower yield per plant was directly and positively influenced by number of flowers per plant, individual flower weight, days to flower bud initiation and shelf life of flowers. Whereas, negative direct influence by days taken for fifty per cent flowering, number of primary branches and duration of flowering were noticed. Further, the path coefficient analysis (phenotypic) revealed that flower yield per plant had positive direct effect from number of flowers per plant, individual flower weight, days taken for flower bud initiation, flower diameter and shelf life of flowers; whereas, negative direct effect through days taken for fifty per cent flowering was noticed. Hence, selection for these traits would be effective for flower yield improvement in chrysanthemum.

\section{Introduction}

Flowers and flowering plants are fascinating part of our life. Among them, chrysanthemum (chryos - golden; anthos - flower) called as "Queen of the East" is a most interesting and popular flower crop of commercial importance. It ranks third in the International cut flower trade next to rose and carnation in demand and popularity. Chrysanthemum is native to China, belonging to the family Asteraceae which is the most phylogenetically advanced dicotyledonous family. The inflorescence is called as capitulum or head consisting of large number of tiny florets closely mounted on a flattened stem end, which gives a false appearance of single bloom. Garden chrysanthemum which was previously known as Chrysanthemum morifolium (Ramat) and now it is called as Dendranthema grandiflora (Tzvelev) Kumbar et al., (2017) In India chrysanthemum commercially cultivated in states like Tamil Nadu, Karnataka, Maharashtra, Rajasthan, 
Madhya Pradesh and Bihar. Its cultivation is popular around the cities like Delhi, Kolkata, Lucknow, Kanpur, Chennai, Allahabad and Bengaluru. It is grown in an area of 5,453 ha with production of $59,543 \mathrm{Mt}$ and productivity of $10.92 \mathrm{t} / \mathrm{ha}$ in Karnataka for loose flower purpose (Anon., 2016). Still, there is a need to increase chrysanthemum cultivation which is limiting due to lack of high yielding varieties with attractive flowers. A study was conducted to study the path analysis of different parameters with yield components and their direct and indirect effects on flower yield.

Correlation coefficient analysis measures the mutual relationship between various plant characters and determines the component characters on which selection can be based for genetic improvement in yield. Yield being a complex character, is collectively influenced by various characters which are polygenically inherited and highly subjected to environment variations. Hence, for an effective and efficient selection of genotypes for yield, the knowledge of direction and magnitude of association between yield and its components and among the components themselves is very much essential. The phenotypic correlations indicate the extent of the observed relationship between two characters. This does not give true genetic picture of the relationship because it includes both heritable and non-heritable association. Genotypic correlations provide an estimate of inherent association between genes controlling any two characters.

Improving genetic correlation was mainly due to pleiotrophy and linkage (Jain, 1982). To split the observed correlations in to direct and indirect effect, the concept of path coefficient analysis was originally developed by Wright (1921), which splits the correlation coefficient into the measures of direct and indirect effect so that relative influence of each component character on yield could be assessed. That in turn helps to select the lines for further crop improvement.

\section{Materials and Methods}

The experiment was conducted to study the correlation of the different morphological characters influencing the flower yield in different genotypes of chrysanthemum (Dendranthema grandiflora Tzvelve). The experimental material comprised of ten chrysanthemum genotypes such as Marigold, Dall White, Karnool, Dall Yellow, Poornima Yellow, Poornima Pink, Calcutta Shantini, Poornima Red, Poornima White and Dundi were evaluated in Complete Randomized Design with three replications during kharif 2017-18 at K. R. C. College of Horticulture, Arabhavi. The plants were planted at a spacing of $60 \mathrm{X} 45 \mathrm{~cm}$ and all the recommended cultural practices were followed. Five competitive plants were tagged at random in each treatment in each replication for recording detailed observation and the data were recorded for all the 12 quantitative and qualitative characters viz., plant height, number of primary and secondary branches, number of leaves at 90 days after planting, leaf area $\left(\mathrm{cm}^{2}\right)$, days taken for flower bud initiation, days for 50 per cent flowering, duration of flowering (days), number of flowers per plant, individual flower weight $(\mathrm{g})$, diameter of flower $(\mathrm{cm})$, shelf life $(\mathrm{h})$ and flower yield per plant (g/plant) were recorded. Mean values were subjected to analysis of variance, genotypic and phenotypic path analysis was carried out separately to know the direct and indirect effects of the important components, which are the standardized partial regression. Coefficients were obtained by solving the following set of ' $p$ ' simultaneous equations through the use of 'Doo-little techniques' as given by Goulden (1959). The direct and indirect effects were classified based on the scale given by Lenka and Mishra (1973). 
More than 1.0 - Very high

0.30 to 0.99 - High

0.20 to 0.29 - Moderate

0.10 to 0.19 - Low

0.00 to 0.09 - Very low

\section{Results and Discussion}

The genotypic and phenotypic path analysis studies were carried out for the 12 characters to know the nature of relationship existing between flower yield per plant (g/plant) and its other component characters (Table 1).

\section{Path coefficient analysis}

The correlation coefficients only indicate the relationship between independent variable and the dependent variable without specifying cause and effect of relationship.

Using Path coefficient analysis, it is possible to resolve the correlations, which will provide an indirect contribution of different quantitative traits. The analysis was done for flower yield per plant, which is dependent variable. Genotypic and phenotypic paths for the dependent variable were computed.

\section{Genotypic path coefficient analysis for flower yield per plant}

The path analysis of flower yield per plant was done with twelve independent characters involving growth, flowering, yield and quality parameters. The matrix of direct and indirect effects presented in the Table 1 .

\section{Genotypic path coefficient analysis}

Number of flowers showed highly significant and positive association for flower yield per plant (0.615). This is mainly because of its direct positive effect (0.803) and indirect positive effect through days taken for flower bud initiation (0.434) and indirect negative effect through individual flower weight (0.419).
Days taken to flower bud initiation showed highly significant and positive association for flower yield per plant (0.563). This is mainly because of its high direct positive effect (0.657) and indirect positive effect through number of flowers (0.531) and indirect negative effect through days to fifty per cent flowering (-0.466) and individual flower weight $(-0.143)$.

Shelf life of flowers had significant and positive association for flower yield per plant (0.365). This is mainly because of its high direct positive effect $(0.381)$ and indirect positive effect through individual flower weight (0.366) and indirect negative effect through days taken for fifty per cent flowering $(-0.223)$ and number of flowers $(-0.170)$.

Duration of flowering had highly significant and negative association for flower yield per plant (-0.652).

This is mainly because of its direct negative effect (-0.125) and indirect positive effect through days to 50 per cent flowering (0.109) and indirect negative effect through individual flower weight (-0.364) and shelf life (-0.213).

\section{Flower yield per plant as dependent variable}

Flower yield per plant was directly and positively influenced by number of flowers per plant (0.803), individual flower weight (0.713), days to flower bud initiation (0.657) and shelf life of flowers (0.381).

Whereas, negative direct effects by days taken for fifty per cent flowering (-0.544), number of primary branches $(-0.167)$ and duration of flowering $(-0.125)$ were noticed.

The path coefficient analysis for flower yield per plant was carried out considering twelve component and complementary characters. 
Table.1 Genotypic and phenotypic path coefficient analysis of different quantitative and qualitative characters in chrysanthemum genotypes

\begin{tabular}{|c|c|c|c|c|c|c|c|c|c|c|c|c|c|c|c|}
\hline & & $\mathrm{X} 1$ & $\mathbf{X} 2$ & $\mathbf{X 3}$ & $\mathrm{X} 4$ & X5 & X6 & $\mathbf{X 7}$ & X8 & X9 & $\mathrm{X} 10$ & X11 & X12 & $\mathbf{r G}$ & $\mathbf{r P}$ \\
\hline X1 & G & -0.034 & -0.050 & 0.179 & -0.016 & -0.013 & 0.165 & -0.070 & -0.036 & 0.542 & -0.416 & -0.019 & 0.049 & \multirow[t]{2}{*}{0.282} & \multirow[t]{2}{*}{0.205} \\
\hline & $\mathbf{P}$ & -0.013 & 0.006 & 0.007 & 0.007 & -0.034 & 0.075 & -0.028 & 0.000 & 0.625 & -0.398 & -0.060 & 0.018 & & \\
\hline $\mathrm{X} 2$ & G & -0.010 & -0.167 & 0.066 & 0.004 & -0.007 & -0.142 & 0.045 & 0.037 & -0.233 & 0.038 & 0.033 & 0.233 & \multirow[t]{2}{*}{-0.104} & \multirow[t]{2}{*}{-0.133} \\
\hline & $\mathbf{P}$ & -0.003 & 0.027 & 0.004 & -0.002 & -0.018 & -0.062 & 0.013 & 0.000 & -0.289 & 0.029 & 0.090 & 0.079 & & \\
\hline X3 & G & -0.027 & -0.050 & 0.222 & -0.007 & -0.008 & -0.164 & 0.224 & -0.053 & 0.302 & -0.653 & 0.002 & -0.131 & \multirow[t]{2}{*}{-0.342} & \multirow[t]{2}{*}{-0.153} \\
\hline & $\mathbf{P}$ & -0.007 & 0.009 & 0.012 & 0.003 & -0.021 & -0.075 & 0.081 & 0.000 & 0.338 & -0.461 & 0.019 & -0.050 & & \\
\hline $\mathrm{X} 4$ & G & -0.021 & 0.026 & 0.064 & -0.026 & 0.004 & 0.560 & -0.362 & -0.032 & 0.633 & -0.452 & -0.066 & -0.035 & \multirow[t]{2}{*}{0.294} & \multirow[t]{2}{*}{0.260} \\
\hline & $\mathbf{P}$ & -0.007 & -0.005 & 0.002 & 0.013 & 0.013 & 0.296 & -0.172 & 0.000 & 0.816 & -0.462 & -0.222 & -0.014 & & \\
\hline X5 & G & -0.022 & -0.053 & 0.086 & 0.006 & -0.020 & -0.236 & 0.209 & 0.012 & 0.111 & 0.077 & 0.038 & 0.145 & \multirow[t]{2}{*}{0.352} & \multirow[t]{2}{*}{0.332} \\
\hline & $\mathbf{P}$ & -0.007 & 0.008 & 0.004 & -0.003 & -0.064 & -0.125 & 0.098 & 0.000 & 0.147 & 0.085 & 0.129 & 0.060 & & \\
\hline $\mathrm{X6}$ & G & -0.008 & 0.036 & -0.056 & -0.022 & 0.007 & 0.657 & -0.466 & 0.025 & 0.531 & -0.143 & -0.062 & 0.063 & \multirow[t]{2}{*}{$0.563 * *$} & \multirow[t]{2}{*}{$0.520 * *$} \\
\hline & $\mathbf{P}$ & -0.003 & -0.005 & -0.003 & 0.011 & 0.022 & 0.357 & -0.227 & 0.000 & 0.712 & -0.157 & -0.216 & 0.029 & & \\
\hline $\mathbf{X 7}$ & G & -0.004 & 0.014 & -0.092 & -0.017 & 0.008 & 0.563 & -0.544 & 0.025 & 0.245 & -0.024 & -0.049 & 0.156 & \multirow[t]{2}{*}{0.281} & \multirow[t]{2}{*}{0.273} \\
\hline & $\mathbf{P}$ & -0.001 & -0.001 & -0.004 & 0.008 & 0.023 & 0.302 & -0.268 & 0.000 & 0.333 & -0.020 & -0.169 & 0.069 & & \\
\hline $\mathbf{X 8}$ & G & -0.010 & 0.049 & 0.095 & -0.007 & 0.002 & -0.134 & 0.109 & -0.125 & -0.031 & -0.364 & -0.021 & -0.216 & \multirow[t]{2}{*}{$-0.652 * *$} & \multirow[t]{2}{*}{$-0.573 * *$} \\
\hline & $\mathbf{P}$ & -0.003 & -0.005 & 0.004 & 0.003 & 0.006 & -0.070 & 0.046 & -0.001 & -0.034 & -0.350 & -0.074 & -0.096 & & \\
\hline X9 & G & -0.023 & 0.049 & 0.084 & -0.020 & -0.003 & 0.434 & -0.166 & 0.005 & 0.803 & -0.419 & -0.048 & -0.081 & \multirow[t]{2}{*}{$0.615^{* *}$} & \multirow[t]{2}{*}{$0.620 * *$} \\
\hline & $\mathbf{P}$ & -0.007 & -0.007 & 0.004 & 0.010 & -0.008 & 0.230 & -0.081 & 0.000 & 1.103 & -0.426 & -0.163 & -0.035 & & \\
\hline $\mathrm{X} 10$ & G & 0.020 & -0.009 & -0.204 & 0.016 & -0.002 & -0.132 & 0.018 & 0.064 & -0.472 & 0.713 & 0.035 & 0.195 & \multirow[t]{2}{*}{0.242} & \multirow[t]{2}{*}{0.271} \\
\hline & $\mathbf{P}$ & 0.007 & 0.001 & -0.007 & -0.008 & -0.007 & -0.074 & 0.007 & 0.000 & -0.615 & 0.763 & 0.121 & 0.083 & & \\
\hline $\mathrm{X} 11$ & G & 0.009 & -0.075 & 0.007 & 0.023 & -0.011 & -0.552 & 0.363 & 0.036 & -0.519 & 0.335 & 0.073 & 0.107 & \multirow[t]{2}{*}{-0.203} & \multirow[t]{2}{*}{-0.175} \\
\hline & $\mathbf{P}$ & 0.003 & 0.009 & 0.001 & -0.011 & -0.031 & -0.294 & 0.173 & 0.000 & -0.688 & 0.353 & 0.261 & 0.048 & & \\
\hline $\mathrm{X} 12$ & G & -0.004 & -0.102 & -0.076 & 0.002 & -0.008 & 0.109 & -0.223 & 0.071 & -0.170 & 0.366 & 0.021 & 0.381 & \multirow[t]{2}{*}{$0.365^{*}$} & \multirow[t]{2}{*}{0.326} \\
\hline & $\mathbf{P}$ & -0.001 & 0.012 & -0.004 & -0.001 & -0.022 & 0.059 & -0.105 & 0.000 & -0.221 & 0.361 & 0.072 & 0.176 & & \\
\hline
\end{tabular}

Residual Effect $=0.077 ; *$ and $* *$ indicate significant at 5 and 1 per cent probability level, respectively. $\mathrm{rG}=\mathrm{Genotypic}$ correlation coefficient of flower yield per plant

$\mathrm{rP}=$ Phenotypic correlation coefficient of flower yield per plant; Bold: Direct effect; Above and below diagonal: Indirect effect

\begin{tabular}{l|l|ll} 
X1: Plant height (90 DAP) (cm) & X2: Number of primary branches (90 DAP) & X3: Number of secondary branches (90 DAP)
\end{tabular}

X5: Leaf area $\left(\mathrm{cm}^{2}\right)$

G: Genotypic path coefficient value
X6: Days to flower bud initiation

$\mathrm{X} 10$ : Individual flower weight (g)

G: Phenotypic path coefficient value
$\mathrm{X} 7$ : Days to fifty per cent flowering

$\mathrm{X} 11$ : Flower diameter $(\mathrm{cm})$ 
The residual effect of the genotypic path analysis was low (0.077) indicating that, the characters considered for the path analysis were appropriate for the study and flower yield per plant was taken as a dependent variable. Flower yield per plant had positive direct effect from number of flowers per plant, individual flower weight, flower diameter, number of leaves, plant height and plant spread. Results are in line with Shiragur (2009) and Sahu and Sharma (2014) in chrysanthemum; Rai et al., (2017) and Kumari et al., (2017) in China aster.

\section{Phenotypic path}

The phenotypic path analysis of flower yield per plant was done with twelve independent characters involving growth, flowering, yield and quality parameters. The matrix of direct and indirect effects is presented in the Table 1 .

Number of flowers per plant showed highly significant and positive effect (0.620) on flower yield per plant. This is mainly because of its very high direct positive effect (1.103) and indirect positive effect through days taken for flower bud initiation (0.230) and indirect negative effect through individual flower weight $(-0.163)$.

Days taken for flower bud initiation showed highly significant and positive effect (0.520) on flower yield per plant. This is mainly because of direct positive effect (0.357) and indirect positive effect through number of flowers (0.712) and indirect negative effect through flower diameter (-0.216) and individual flower weight $(-0.157)$.

Duration of flowering showed highly significant and negative effect $(-0.573)$ on flower yield per plant. This is mainly because of its negligible direct negative effect $(-0.001)$ and indirect negative effect through individual flower weight $(-0.350)$ and shelf life of flowers (-0.096).

Flower yield per plant as dependent variable

Flower yield per plant had positive direct effect from number of flowers per plant (1.103), individual flower weight (0.763), days taken for flower bud initiation (0.357), flower diameter (0.261) and shelf life of flowers (0.176). Whereas, negative direct effect through days taken for fifty per cent flowering (-0.268) was noticed.

The path coefficient analysis for flower yield per plant was carried out considering twelve component and complementary characters. The residual effect of the phenotypic path analysis was low (0.105) indicating that, the characters considered for the path analysis were appropriate for the study and flower yield per plant is taken as a dependent variable.

Flower yield per plant was directly and positively influenced by number of flowers per plant, individual flower weight, shelf life and days to flower bud initiation. Similar result was reported for number of branches, number of leaves, leaf area and flower diameter by Sirohi and Behera (1999); Karuppaiah et al., (2004) and Misra et al., (2013) in chrysanthemum, Anuradha and Narayanagowda (2000); Magar et al., (2010) in gerbera; Karuppaiah and Kumar (2010) in marigold. Therefore, direct selection for these traits would reward for improvement of yield. Whereas, negative direct effects through days taken for fifty per cent flowering, number of primary branches and flower duration. Similar results found by Kore (2014) and Kumari et al., (2017) in China aster.

Genotypic path coefficient analysis revealed that flower yield per plant was directly and 
positively influenced by number of flowers per plant, individual flower weight, days to flower bud initiation and shelf life of flowers. Whereas, negative direct influence by days taken for fifty per cent flowering, number of primary branches and duration of flowering were noticed. Further, the path coefficient analysis (phenotypic) revealed that flower yield per plant had positive direct effect from number of flowers per plant, individual flower weight, days taken for flower bud initiation, flower diameter and shelf life of flowers; whereas, negative direct effect through days taken for fifty per cent flowering was noticed. Hence, selection for these traits would be effective for flower yield improvement in chrysanthemum.

\section{References}

Anonymous, 2016, Area and production database, Dept. of Horticulture, Govt. of Karnataka.

Anuradha, S. and Narayanagowda, J. V., 1999, Quantitative genetic studies in gerbera. Mysore J. Agric. Sci., 33 (2): 224-227.

Goulden, C. H., 1959, Methods of statistical analysis, Asia Publishing House, Calcutta.

Jain, S. P., 1982, Statistical techniques in quantitative genetics. Indian agricultural statistics research institute, New Delhi.

Karuppaiah, P., and Kumar, P. S., 2010, Correlation and path analysis in African marigold (Tagetes erecta L.). Electronic J. Plant Breeding, 1(2): 217-220.

Karuppaiah, P., Sudhakaran, K., Kumar, P. S. and Kathiravan, J., 2004, Correlation and path analysis for yield, yield attributes and xanthophylls content in African marigold (Tagetes erecta L.). South Ind. Hort. 54 (1-6): 304-310.

Kore, R., 2014, Studies on genetic variability and molecular characterization in China aster (Callistephus chinensis [L.]
Nees.). M. Sc. (Hort.) Thesis. UHS Bagalkot.

Kumari, P., Kumar, R., Rao, T. M., Dhananjaya, M. V. and Bhargav, V., 2017, Genetic variability, character association and path coefficient analysis in China aster [Callistephus chinensis (L.) Nees]. Hort Flora Research Spectrum. 6(4): 278-282.

Kumbar, I., Patil, C. P., Kulkarni, B. S., Shiragur, M. and Shirol, A. M., 2017, Efficacy of Entrophospora sp. (VA Mycorrhiza) on salt tolerance and flower yield and quality of chrysanthemum var. Marigold (Dendranthema grandiflora Tzvelev). Int.J.Curr.Microbiol.App.Sci. $\quad$ 6(10): 4769-4777.

Lenka, D. and Mishra, B. 1973, Path coefficient analysis of yield in rice varieties. Indian J. Agric. Sci., 43: 376379.

Magar, S. D., Warade, S. D., Nalge, N. A. and Nimbalkar, C. A., 2010, Correlation and path analysis studies in gerbera (Gerbera jamesonii). Int. J. Plant Sci. 5 (2): 553-555.

Misra. S., Mandal. T., Vanlalruati and Das. S. K. 2013, Correlation and path coefficient analysis for yield contributing parameters in spray chrysanthemum. J. Hort. Letters. 3(1): 14-16.

Rai, T. S., Chaudhary, S. V. S., Dhiman, S. R., Dogra, R. K. and Gupta, R. K., 2017, Genetic variability, character association and path coefficient analysis in China aster (Callistephus chinensis). Ind. J. Agri. Res. 87 (4): 540-543.

Sahu, M. and Sharma, G., 2014, Genetic variability, correlation and path analysis for yield and its attributing traits in small flowered chrysanthemum. J. Orn. Hort. 17 (1\&2): 32-37.

Shiragur, M., 2009, Characterization of chrysanthemum

(Dendranthema 
grandiflora Tzvelev.) germplasm through morphological and molecular markers. Ph. D Thesis Univ. Agril. Sci., Bangalore.

Sirohi, P. S. and Behera, T. K., 1999, Correlation and path analysis studies in chrysanthemum. J. Orn. Hort., New Series, 2(2): 80-83.

Wright, S., 1921, Correlation and causation. J. Agric. Res., 20: 557-585.

\section{How to cite this article:}

Mallikarjun Hebbal, Mukund Shiragur, Sandhyarani Nishani, B.C. Patil, G.K. Seetharamu and Mahantesha B.N. Naika. 2018. Genotypic and Phenotypic Path Analysis for Flower Yield in Chrysanthemum (Dendranthema grandiflora Tzvelve). Int.J.Curr.Microbiol.App.Sci. 7(08): 4515-4521. doi: https://doi.org/10.20546/ijcmas.2018.708.478 